\title{
Design of a UV Chamber Prototype With an Internet of Things-Based Control System
}

\author{
Fazrina Saumi, Fitra Mulyani \\ Mathematic Study Program, Faculty of Engineering \\ Universitas Samudra \\ Langsa, Indonesia \\ Halimatussakdiah \\ Chemistry Study Program, Faculty of Engineering \\ Universitas Samudra \\ Langsa, Indonesia
}

\author{
Rachmad Almi Putra* \\ Physics Study Program. Faculty of Engineering \\ Universitas Samudra \\ Langsa, Indonesia \\ *Rachmad.almi@unsam.ac.id
}

\author{
Juniar Afrida \\ Fakultas Tarbiyah dan keguruan \\ UIN Ar-Raniry \\ Banda Aceh, Indonesia
}

\begin{abstract}
A brief summary A UV-Reactor prototype in the form of a UV chamber with an Internet of Things-based control system (IoT) has been successfully developed. The UV chamber that was constructed is $180 \mathrm{~cm}$ in length and is made up of three main parts: two control rooms and one sterilization room. The sterilization room has three UV lamps with a total power of 20 watts and a wavelength of 200 s.d. $240 \mathrm{~nm}$; light with this wavelength range is thought to be capable of degrading DNA or RNA found in bacteria or viruses. The UV chamber control system was developed using the Internet of Things (IoT) and can be controlled using the Blynk application on an Android-based smartphone. The intensity of the UV source in the chamber can be changed by changing the resistance with a smartphone without altering the wavelength of the source.
\end{abstract}

Keywords-UV chamber, Things-based control system (IoT), Introduction, covid 19

\section{INTRODUCTION}

Coronavirus, also known as Corona Virus Disease (Covid), was discovered in Wuhan, China in 2019 and is known as Covid19 [1]. Covid19 is a global outbreak that has claimed many lives so far. In most cases, people with Covid19 show no symptoms until they become out of breath. In some cases, people with covid recover and are unaware that they are agents or carriers of viruses that can be passed on to others. This virus resembles cov-2, MERS, and SARS in appearance. The protective membrane protein or protective RNA of this virus, on the other hand, is thicker and contains more RNA. As a result, it is believed that this virus will be able to survive the previous covid virus [2]. Various attempts are made to spread the virus regularly. A study on efforts to stop the virus from spreading was undertaken by Unhale et al. [1]. The temperature did not affect the growth of Covid19 in this research, according to the findings. Other researches have found that when viruses, bacteria, and fungi are exposed to UV rays for a longer time, their growth is inhibited [3-5]. Some UV rays, on the other hand, can be harmful to the body, causing skin cancer or lupus. According to research Katara et al. [6], virus growth in aerosols decreases as UV light intensity increases [7]. The UV light used comes from an LED array that can produce UV-C light and is used in chamber UV to sterilize equipment [8]. Furthermore, Mcdevitt et al. [9] observed the growth and development of viruses in the chamber using the PCR analysis method, explaining that exposure to UV-C rays can inactivate the virus due to RNA degradation in the virus, resulting in the virus no longer being active.

Based on the foregoing context, there are still research gaps in attempts to combat Covid19, both in terms of its spread and the healing and sterilization of Covid19-affected areas. As a result, researchers are keen to investigate the Design of UV Reactors as Covid-19 Sterilization Chambers. The designed prototype chamber can be monitored by the intensity of UV light exposure without changing the wavelength of the light, which is a unique feature of this study. Furthermore, the control system is based on IoT and is monitored using the Blynk application on a smartphone.

The Internet of Things (IoT) refers to a vast number of "things" that are connected to the internet so they can share data with other things - IoT applications, connected devices, industrial machines and more. Internet-connected devices use built-in sensors to collect data and, in some cases, act on it. IoT connected devices and machines can improve how we work and live. Real-world Internet of Things examples range from a smart home that automatically adjusts heating and lighting to a smart factory that monitors industrial machines to look for problems, then automatically adjusts to avoid failures. 


\section{METHODS}

\section{A. Control System Circuit Schematic and UV Prototype} Chamber Design

A Nodemcu and a 4 Channel Relay are linked to a UV lamp via an AC voltage coupled in a UV chamber in the built circuit schematic. Figure 1 depicts the form of a series of UV images, while Figure 2 depicts the UV chamber construction.

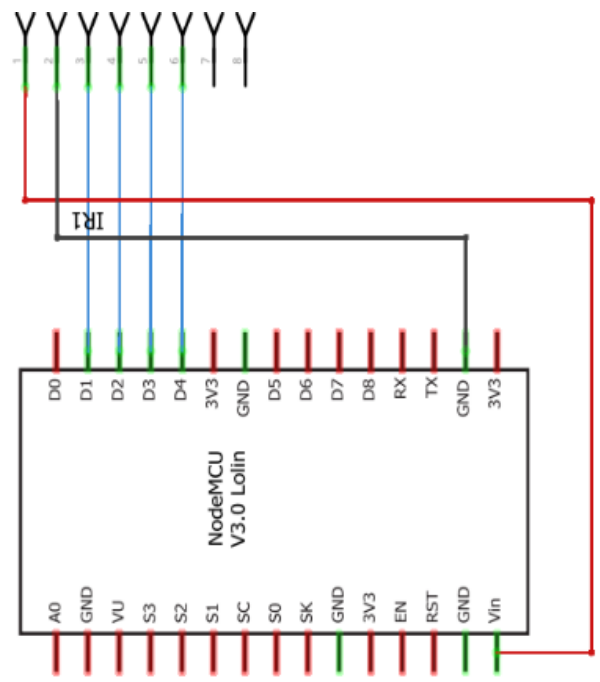

Fig. 1. UV chamber control circuit schematic design.

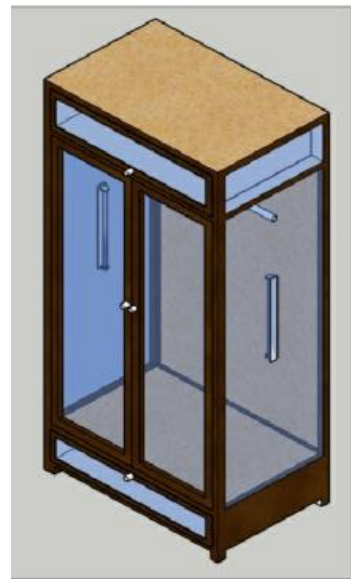

Fig. 2. UV prototype chamber design.

\section{B. Design of the System}

The IoT-based control system is used. The chamber's work system is depicted in Figure 3 below

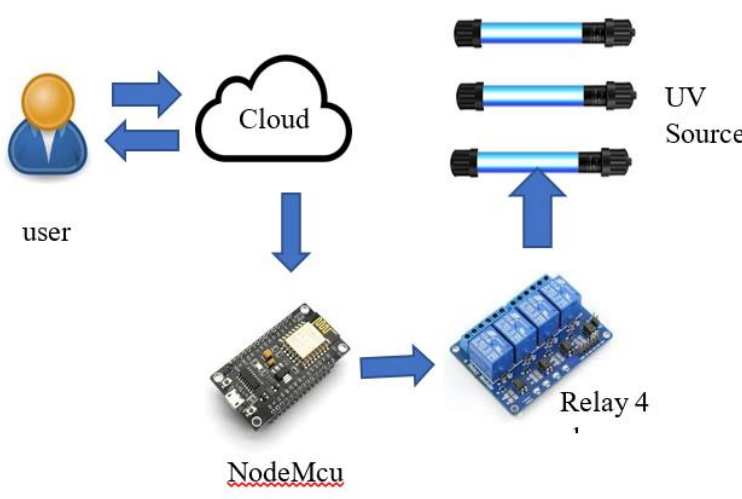

Fig. 3. Workflow of the system.

\section{RESULTS AND DISCUSSION}

\section{A. UV Chamber}

The UV-Vis prototype chamber, which consists of three UV light sources of the UV-C type, has been completed successfully. Its wavelength ranges from 200 to $240 \mathrm{~nm}$. Below $280 \mathrm{~nm}$, the resulting wavelength spectrum has enough energy to damage or break DNA or RNA bonds in viruses and bacteria The degree of DNA bond damage or microorganism inactivation is highly dependent on the length of UV light exposure. The amount of time required for UV exposure is determined by the UV radiation's intensity and energy. The lamp power is 20 watts, with a 13.5-watt output power efficiency. Table 1 shows the results of using a Lux Meter to measure the effect of the amount of resistance on the intensity of the resulting UV rays.

TABLE I Results of Using A LuX METER TO MEASURE THE EFFECT OF THE AMOUNT OF RESISTANCE ON THE INTENSITY OF THE RESULTING UV RAYS

\begin{tabular}{|l|l|}
\hline $\mathbf{R}(\mathbf{o h m})$ & \multicolumn{1}{|c|}{ UV Intensity (cd) } \\
\hline 10 & 1128 \\
\hline 12 & 1018 \\
\hline 14 & 981 \\
\hline 16 & 946 \\
\hline 18 & 870 \\
\hline 20 & 810 \\
\hline
\end{tabular}

The higher the resistance that is diverse, the lower the intensity of the UV rays produced, as can be seen from these statistics. Figure 4 depicts the following information graphically. 


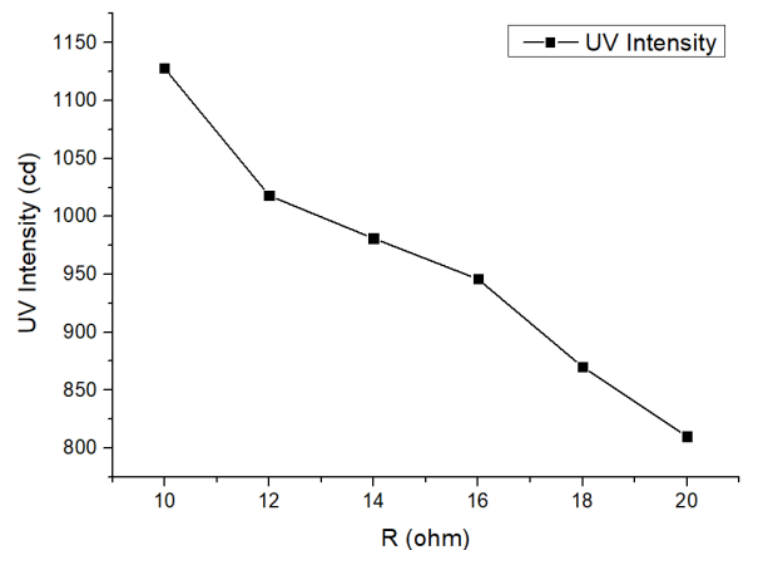

Fig. 4. Resistance to intensity relationship.

The trend is decreasing with the increasing resistance, as can be seen from the graph. This is due to a decrease in the load voltage supply (Vout), which is caused by increasing resistance, as can be seen from the logger data information produced in Table 2.

TABLE II. ADC TABLE VS RESISTANCE

\begin{tabular}{|l|l|}
\hline \multicolumn{1}{|c|}{ ADC } & R (ohm) \\
\hline 98767 & 10 \\
\hline 78121 & 12 \\
\hline 64129 & 14 \\
\hline 58312 & 16 \\
\hline 48812 & 18 \\
\hline 38189 & 20 \\
\hline
\end{tabular}

The higher the resistance value, the lower the intensity produced and the lower the resulting output voltage, according to the data collected by the two tables.

\section{B. UV Control Chamber System Working Principle Chamber}

The UV source in the UV chamber is operated by a smartphone that has been configured with the open-source Blynk application and integrated with nodemcu through the Blynk API. The user's instructions are converted into a data signal, which is then sent to the Blynk server, where it is processed into a set of instructions that are forwarded to the client, namely nodemcu and the associated series. The information and instructions received from the blynk server at nodemcu are processed and forwarded in the form of digital or analog signals to control the devices connected to it. The user's intensity variation is changing the resistance value, which then affects the output voltage value on UV (Vout), changing the resulting intensity value.

\section{CONCLUSIONS}

Based on the debate, a UV reactor in the form of a UV chamber with a wavelength in the $200-240 \mathrm{~nm}$ range that can be varied in intensity value by changing the output voltage (Vout) by increasing the resistance value has been successfully developed. The smaller the voltage output value and the resulting intensity value, the greater the resistance value. The variation in resistance values from 10 to $20 \mathrm{ohms}$ with a $2-\mathrm{ohm}$ rise, with ADC values in the range 98767 to 38189, and decreases in intensity from 1128 to 810 candela were derived from the data.

\section{ACKNOWLEDGMENT}

DIPA Universitas Samudra financed this research through superior lecturer research coordinated by LPPM-PM under contract number 363/UN54.6/PG/2020.

\section{REFERENCES}

[1] S.S. Unhale, Q.B. Ansar, S. Sanap, S. Thakhre, and S. Wadatkar, "a Review on Corona Virus ( Covid-19 )," World J. Pharm. Life Sci., vol. 6, no. 4, pp. 109-115, 2020.

[2] A. Seyer and T. Sanlidag, "Solar ultraviolet radiation sensitivity of SARS-CoV-2," The Lancet Microbe, vol. 1, no. 1, pp. e8-e9, 2020.

[3] C.C.L.R.I. Theory Division et al., "UV Sterilization of Personal Protective Equipment with Idle Laboratory Biosafety Cabinets During the Covid-19 Pandemic," medRxiv, p. 2020.03.25.20043489, 2020.

[4] M. E. R. Darnell, K. Subbarao, S. M. Feinstone, and D. R. Taylor, "Inactivation of the coronavirus that induces severe acute respiratory syndrome, SARS-CoV," J. Virol. Methods, vol. 121, no. 1, pp. 85-91, 2004.

[5] Y. Fu, P. Han, R. Zhu, T. Bai, J. Yi, X. Zhao and W. Yan, "Risk Factors for Viral RNA Shedding in COVID-19 Patients," Eur. Respir. J., p. 2001190, 2020

[6] G. Katara, N. Hemvani, S. Chitnis, V. Chitnis, and D. Chitnis, "Surface disinfection by exposure to germicidal UV light," Indian J. Med. Microbiol., vol. 26, no. 3, pp. 241-242, 2008.

[7] D. Kim and D. Kang, "crossm UVC LED Irradiation Effectively Inactivates Aerosolized Viruses ," vol. 84, no. 17, pp. 1-11, 2018.

[8] H. Aeran, S. Sharma, V. Kumar, and N. Gupta, "Use of clinical UV chamber to disinfect dental impressions: A comparative study," J. Clin. Diagnostic Res., vol. 9, no. 8, pp. ZC67-ZC70, 2015.

[9] J.J. Mcdevitt, S.N. Rudnick, and L.J. Radonovich, "Aerosol Susceptibility of Influenza Virus to UV-C Light,” pp. 1666-1669, 2012. 